\title{
Sistem Informasi Pendaftaran Seminar Dengan Tiket Berbasis Qr Code
}

\author{
Dwi Arianto Adi Nugroho, Heru Supriyono \\ Program Studi Informatika \\ Universitas Muhammadiyah Surakarta \\ Surakarta, Indonesia \\ dwiariantoan@gmail.com, Heru.Supriyono@gmail.com
}

\begin{abstract}
Abstraksi-Perkembangan teknologi informasi di Era sekarang ini sangat pesat, salah satunya adalah Qr Code. Quick Response Code (Qr Code) adalah bentuk evolusi kode batang dari satu dimensi menjadi dua dimensi. Dalam sebuah acara seminar, peserta harus mendaftar terlebih dahulu untuk mendapatkan tiket yang digunakan untuk masuk kedalam acara seminar dan tiket tersebut masih menggunakan tiket dalam bentuk kertas atau yang biasa disebut dengan tiket konvensional. Untuk mengatasi masalah yang terjadi maka diperlukan sistem pendaftaran siminar online dengan tiket berbasis Qr Code. Tujuan dibuatnya sistem ini adalah untuk meningkatkan efisiensi waktu dalam pendaftaran di sebuah seminar. Sistem ini memanfaatkan Qr Code sebagai komponen utama dimana Qr Code sebagai primary key yang berisi data user dan webcam sebagai alat untuk membaca data $\mathrm{Qr}$ Code pada tiket yang diunduh oleh user serta Personal Computer (PC) untuk menjalankan sistem yang sudah dibangun. Sistem ini dibuat dengan bahasa pemrograman hypertext prepocessor (PHP) dengan framework Bootstrap dan MySQL untuk database. Perancangan sistem ini menggunakan metode System Development Life Cycle (SDLC). Hasil dari pengujian yang dilakukan oleh client dan user menggunakan metode blackbox telah berhasil sesuai dengan tujuan program dibuat yaitu membantu proses pendaftaran agar lebih efisien. Berdasarkan pengujian dengan membagikan kuesioner yang diberikan kepada calon pengguna dapat diketahui sebanyak $91.47 \%$ responden setuju jika sistem ini efisien dan layak untuk digunakan.
\end{abstract}

Katakunci-seminar; qr code; pendaftaran online; tiket

\section{Pendahuluan}

Perkembangan teknologi informasi di Era sekarang ini sangat pesat. Dengan kemajuan teknologi informasi, mengakses data atau informasi dapat berlangsung dengan cepat dan akurat. Quick Response Code (Qr Code) adalah bentuk evolusi kode batang dari satu dimensi menjadi dua dimensi. Gagasan di balik pengembangan kode QR adalah keterbatasan kapasitas informasi barcode (hanya dapat menampung 20 karakter alfanumerik) [1]. Biaya penerapan Qr Code jauh lebih murah dibandingkan dengan radio frequency identification (RFID) atau teknologi lainnya [2].
Seminar adalah sebuah pertemuan yang bertujuan untuk membahas suatu masalah secara ilmiah. Untuk menghadiri acara seminar, beberapa seminar menggunakan tiket sebagai akses masuk. Tiket adalah sebuah tanda masuk yang digunakan untuk mendatangi atau menghadiri sebuah tempat/acara tertentu. Dalam sebuah acara seminar, peserta harus mendaftar terlebih dahulu untuk mendapatkan tiket yang digunakan untuk masuk kedalam acara seminar dan tiket tersebut masih menggunakan tiket dalam bentuk kertas atau yang biasa disebut dengan tiket konvensional. Permasalahan yang timbul dari penggunaan tiket konvensional dalam acara seminar tersebut yaitu tidak efisiensinya waktu karena mengharuskan peserta untuk datang ke suatu tempat yang telah ditentukan untuk mendaftar dan mengambil tiket seminar. Dengan menggunakan sistem Qr Code akan mempercepat proses kehadiran [3]. Informasi diakses dengan menangkap sebuah kode dalam bentuk foto dengan menggunakan kamera (misalnya dengan smartphone) dan menangani kode tersebut dengan pembaca QR [4].

Berdasarkan permasalahan tersebut, penulis bermaksud mengadakan penelitian dengan judul "Sistem Informasi Pendaftaran Seminar Dengan Tiket Berbasis Qr Code". Diharapkan dapat digunakan sebagai salah satu alat yang dapat mempermudah peserta seminar untuk menghadiri acara seminar tersebut.

\section{METODE}

Metodologi dalam penelitian yang digunakan dalam pembuatan sistem informasi pendaftaran seminar dengan tiket berbasis Qr Code menggunakan beberapa tahapan, yang pertama melakukan observasi dan wawancara kepada organisasi/instansi yang merencanakan acara seminar serta orang yang pernah mengikuti sebuah acara seminar, setelah itu tahapan perancangan dengan menggunakan metode System Development Life Cycle (SDLC) waterfall. Gambar 1 menunjukan metode SDLC waterfall. 


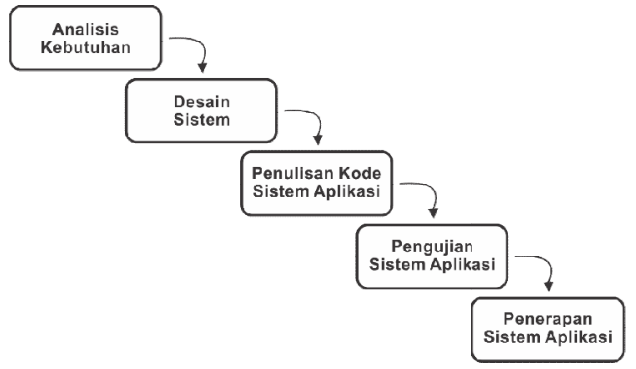

Gambar 1.Metode SDLC waterfall [5]

\section{A. Analisis Kebutuhan Sistem}

Tahap ini mengumpulkan informasi dan menganalisa kebutuhan sistem yang akan dikerjakan. Proses pengumpulan data dalam pembangunan sistem ini dilakukan dengan cara observasi dan melakukan wawancara kepada organisasi/instansi yang merencanakan acara seminar serta orang yang pernah mengikuti sebuah acara seminar. Pada sitem ini juga diperlukan Qr Code generator, Qr Code scanner dan sistem pendaftaran seminar.

\section{B. Analisis Kebutuhan Perangkat Keras (Hardware)}

Perangkat keras yang digunkan yaitu leptop dan webcam. Leptop tersebut digunakan untuk mengoprasikan sistem pendaftaran seminar, webcam disini digunakan untuk membaca data dari Qr Code.

\section{Analisis Kebutuhan Perangkat Lunak (Software)}

Perangkat Lunak yang digunakan yaitu XAMPP versi 3.2.2 sebagai server localhost dimana sistem dan database di simpan, browser digunkan untuk menampilakan halaman sistem dan notepad ++ digunakan untuk penulisan coding untuk sistem yang akan dibuat.

\section{Perancangan Sistem Aplikasi}

Perancangan sistem akan menjelaskan tentang cara kerja sistem, use case diagram, perancangan basis data, perancangan user interface. Admin diberikan hak akses penuh dalam sistem ini. Menu yang terdapat dalam halaman admin yaitu login, mengakses menu pengelolaan data seperti $a d d$, edit serta delete data client dan data seminar, lalu edit serta delete data user, data Qr Code user, view bukti pembayaran user, update status pembayaran user dan view data kehadiran user berdasakan seminar yang diikuti user, memiliki fungsi export data client, data user dan data kehadiran ke dalam dokumen Excel dan menu logout. Client diberikan hak akses untuk mengelola seminar yang di adakan client itu sendiri seperti edit serta delete data user, edit data seminar, melihat bukti pembayaran serta update status pembayaran, melihat data Qr Code, melihat data kehadiran, memiliki fungsi export data user dan data kehadiran ke dalam dokumen Excel, menu login dan logout. Sedangkan untuk user, ada dua tipe user berdasarkan seminar yang yang diikutinya yaitu seminar berbayar dan gratis. Untuk user berbayar didiberikan hak akses login, melihat informasi prosedur seminar, pembayaran seminar serta upload bukti pembayaran, tombol untuk mengunduh tiket, informasi seputar seminar dan menu logout, sedangkan user gratis didiberikan hak akses login, melihat informasi prosedur seminar, generate tiket, tombol untuk mengunduh tiket, informasi seputar seminar dan menu logout.

\section{1) Cara Kerja Sistem}

Client terlebih dahulu menghubungi admin untuk menambahkan seminar yang akan diadakan oleh client, kemudian admin menambahkan seminar berdasarkan seminar yang akan diadakan client dengan memasukan nama seminar, alamat seminar, tanggal mulai dan tanggal selesai seminar, tanggal berakhir pendaftaran, jumlah peserta maksimal, harga seminar, berita seminar, nomor whatsapp, nomor rekening dan upload poster seminar, lalu menambahkan client tersebut agar bisa mengelola seminar dengan memasukan nama seminar yang akan dikelola, nama client, email, password, alamat dan nomor whatsapp. Sketsa perancangan penambahan seminar dan client dapat dilihat pada Gambar 2. Untuk mengikuti acara seminar, user terlebih dahulu memilih seminar yang akan diikuti, jika user memilih seminar berbayar, user lalu melakukan pendaftaran seminar dengan memasukan nama, email, password, alamat dan nomor whatsapp, lalu melakukan login menggunkan email dan password, setelah itu melakukan konfirmasi pembayaran dengan mengunggah bukti pembayaran, lalu client melihat bukti pembayaran tersebut sudah masuk ke rekening atau belum, jika sudah client mengganti status pembayaran dan user baru bisa mengunduh tiket yang ada di halaman tersebut agar mendapatkan file PDF yang berisi Qr Code. Jika user memilih seminar gratis, user melakukan pendaftaran lalu login, setelah itu user generate tiket lalu mengunduh tiket file PDF yang berisi Qr Code tersebut. File PDF tersebut digunakan untuk user saat memasuki acara seminar, file yang berisi Qr Code tersebut dihadapkan ke webcam yang terintergrasi dengan sistem pada menu halaman client untuk proses scanning, dimana nanti data yang disimpan dalam Qr Code akan dipanggil dan menampilkan data user tersebut diperbolehkan masuk ke dalam acara seminar tersebut. Sketsa perancangan pendaftaran seminar untuk user dapat dilihat pada Gambar 3.

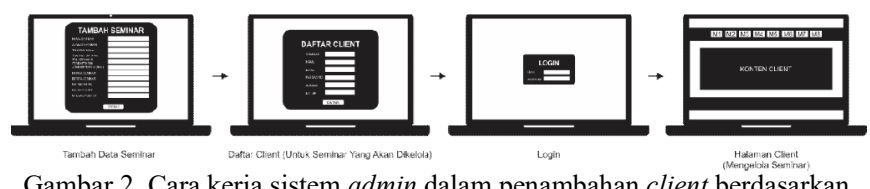

Gambar 2. Cara kerja sistem admin dalam penambahan client berdasarkan seminar yang akan dikelola

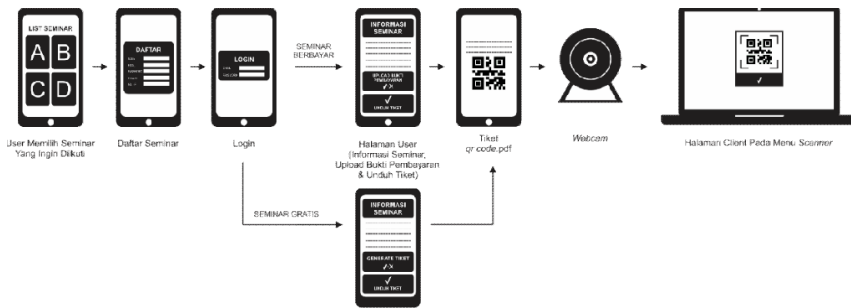

Gambar 3. Cara kerja sistem untuk user pada seminar berbayar dan gratis 


\section{2) Use Case Diagram}

Use Case Diagram mendiskripsikan sebuah interaksi antara satu atau lebih aktor dengan sistem yang akan dibuat. Admin diberikan hak akses untuk mengelola data seminar dan data client seperti add, edit serta delete, admin juga bisa mengubah dan menghapus data user, melihat bukti pembayaran serta update status pembayaran user, menghapus data Qr Code user dan memiliki fungsi export data client, user serta kehadiran ke dalam dokumen Excel. Sedangkan user memiliki hak akses mengubah data seminar, mengubah dan menghapus data user, melihat bukti pembayaran dan update status pembayaran user, menghapus data Qr Code user dan memiliki fungsi export data user dan kehadiran ke dalam dokumen Excel. User di beri hak akses melihat prosedur seminar, informasi seminar serta status pembayaran, update status pembayaran dan unduh tiket seminar. Gambar 4 merupakan diagram use case admin, client dan user.

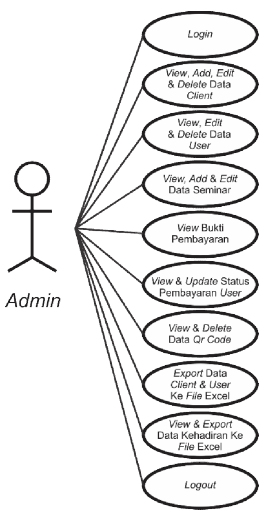

a. Use case diagram admin

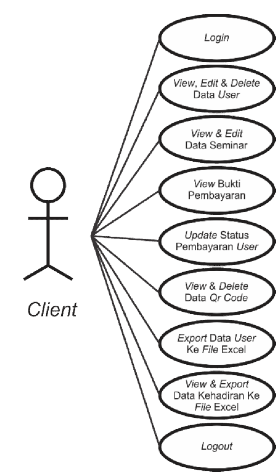

b. Use case diagram

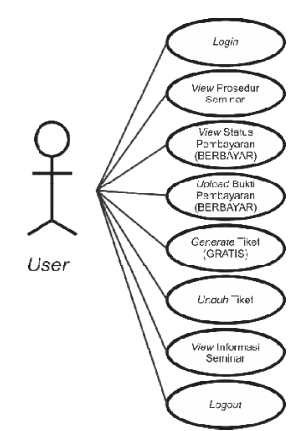

c. Use case diagram

user
Gambar 4. Diagram use case

\section{3) Perancangan Basis Data}

Gambar 5 merupakan hubungan tabel pada satu database yang meliputi user, seminar, qrcode dan kehadiran.

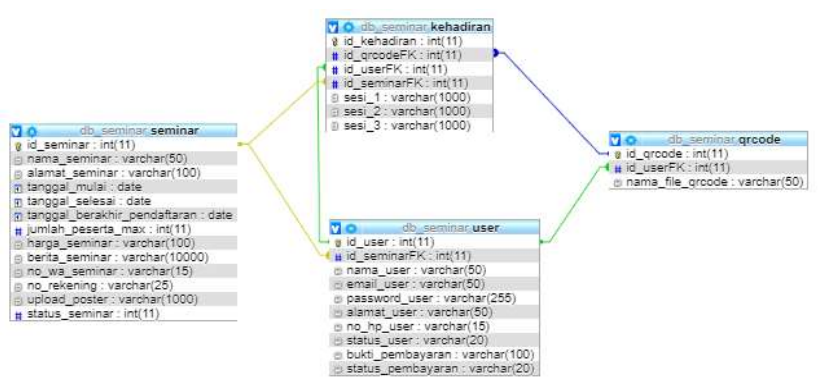

Gambar 5. Rancangan basis data

\section{4) Perancangan User Interface}

Tahap perancangan User Interface digunakan untuk menggambarkan tampilan yang akan di buat. Tampilan sistem pendaftaran seminar sendiri terdiri dari halaman utama, daftar seminar, tambah seminar, daftar client, login, halaman admin, client serta user dan halaman scan.

Pada halaman utama seperti pada rancangan tampilan Gambar 6 nantinya digunakan untuk user ketika ingin memilih seminar yang akan diikuti.

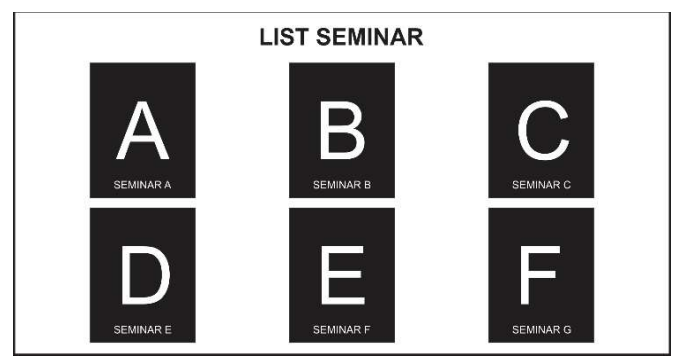

Gambar 6. Rancangan halaman utama

Halaman login seperti pada rancangan tampilan Gambar 7 menampilkan sebuah form login yang berisi email dan password dan juga tombol navigasi yang menuju ke halaman admin, client atau user.

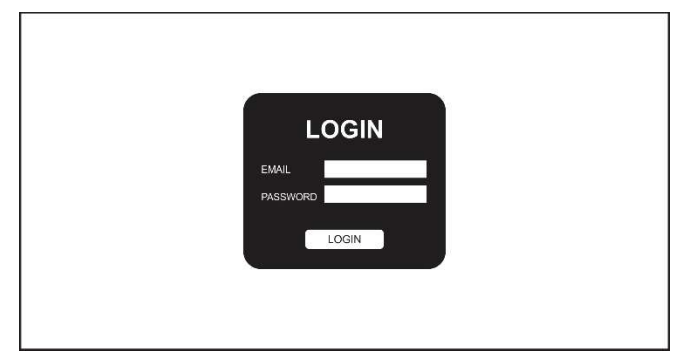

Gambar 7. Rancangan halaman login

Pada halaman admin menampilkan menu-menu untuk pengelolaan data seperti add, edit serta delete data client dan data seminar, lalu edit serta delete data user, data Qr Code user, view bukti pembayaran user, update status pembayaran user dan view data kehadiran user berdasakan seminar yang diikuti user. Pada halaman ini juga memiliki fungsi export data client, data user dan data kehadiran ke dalam dokumen Excel. Desain rancangan halaman admin digambarkan seperti pada Gambar 8.

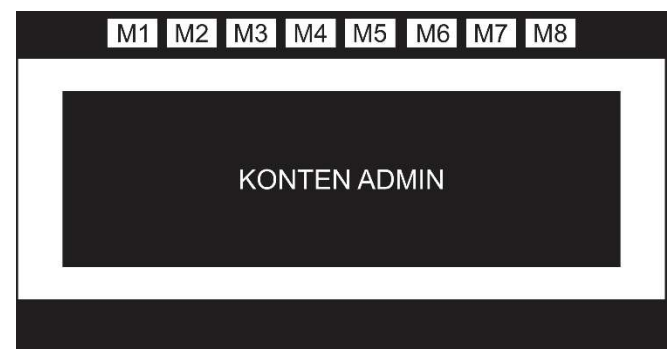

Gambar 8. Rancangan halaman admin 
Halaman Client seperti pada rancangan tampilan Gambar 9 untuk menampilkan menu-menu untuk mengelola data user seperti edit serta delete, edit data seminar, view bukti pembayaran serta update status pembayaran, view data $\mathrm{Qr}$ Code dan data kehadiran. Pada halaman client juga memiliki fungsi export data user dan data kehadiran ke dalam dokumen Excel.

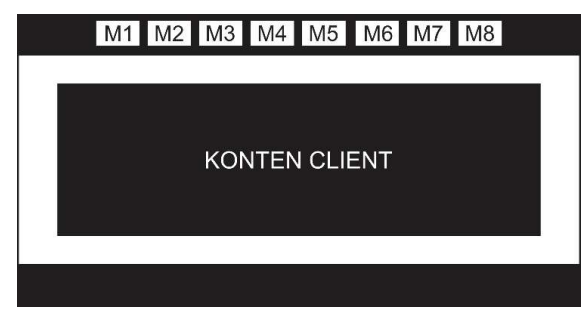

Gambar 9. Rancangan halaman client

Pada halaman user ada dua jenis berdasarkan seminar yang diikuti, yaitu berbayar dan gratis. Pada user seminar berbayar menampilkan informasi prosedur seminar, pembayaran seminar serta upload bukti pembayaran, tombol untuk mengunduh tiket dan informasi seputar seminar, sedangkan pada user seminar gratis menampilkan informasi prosedur seminar, generate tiket, tombol untuk mengunduh tiket dan informasi seputar seminar .Desain rancangan halaman user digambarkan seperti pada Gambar 10.

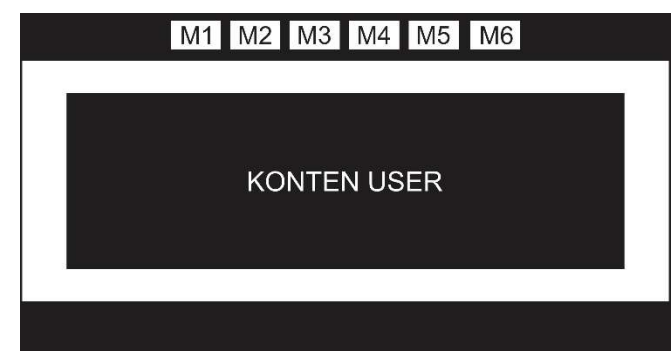

Gambar 10. Rancangan halaman user

Halaman Scan seperti pada rancangan tampilan Gambar 11 digunakan untuk client, halaman ini untuk menampilkan fungsi scanner, yaitu untuk memindai tiket yang berisi Qr Code yang sudah di unduh user.

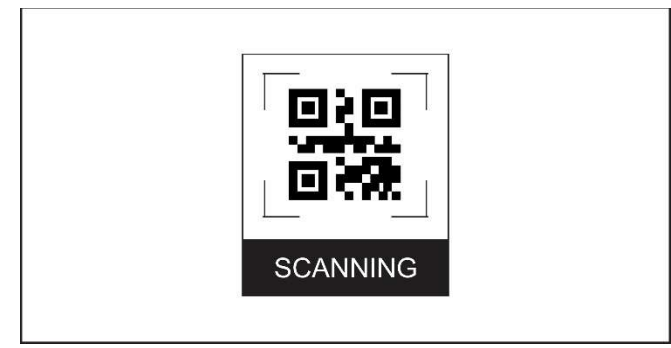

Gambar 11. Rancangan halaman scan

\section{E. Pengujian Aplikasi}

Pada tahap ini pengujian bertujuan untuk mengetahui apakah fitur-fitur yang terdapat dalam sistem pendaftaran seminar tersebut berjalan sesuai dengan rencana. Metode yang digunakan dalam penelitian ini adalah metode blackbox. Pengujian ini nantinya akan dilakukan oleh organisasi/instansi yang mengadakan acara seminar.

\section{Hasil Dan Pembahasan}

\section{A. Hasil}

Hasil yang dicapai dari sistem ini menghasilkan sebuah sistem pendaftaran seminar online dengan tiket berbasis Qr Code yang berisi data client, data user, data seminar, data pembayaran user, data Qr Code user, dan data kehadiran berdasarkan seminar yang diikuti user. Sistem ini memiliki 3 hak akses sesuai dengan status yang sudah di simpan dalam database dimana admin dapat masuk ke halaman utama dan halaman admin, client dapat masuk ke halaman utama dan halaman client serta user dapat masuk ke halaman utama dan halaman user.

Halaman awal merupakan halaman utama yang berisi list seminar yang bisa diikuti oleh user. User bisa memilih seminar dari list seminar tersebut lalu mendaftarakan diri untuk mengikuti seminar yang ingin diikuti. Halaman utama bisa dilihat pada Gambar 12 .

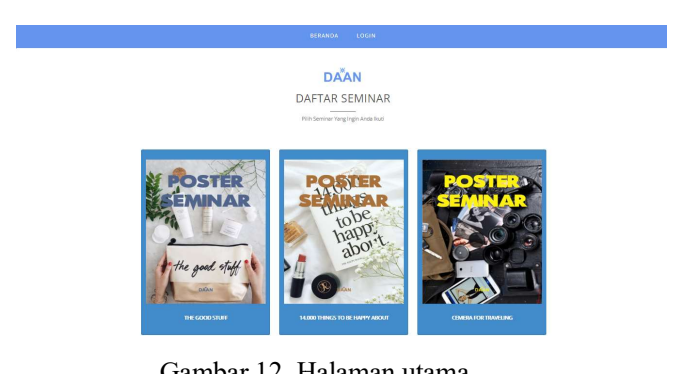

Halaman login merupakan halaman yang akan digunakan oleh admin, client maupun user yang mengharuskan mengisi email dan password. Halaman ini akan menuju ke halaman 
sesuai dengan statusnya. Halaman login bisa dilihat pada Gambar 13.

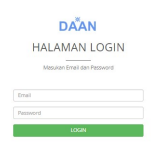

Gambar 13. Halaman login

Pada halaman admin menampilkan navigation/header yang berisi menu pengelolaan data client, data user, data seminar, data pembayaran user, data Qr Code user dan data kehadiran berdasarkan seminar yang diikuti user. Halaman admin ditunjukan pada Gambar 14.

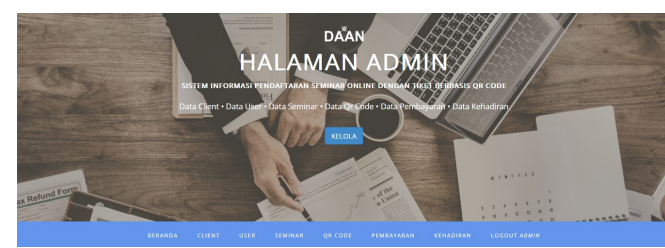

Gambar 14. Halaman admin

Gambar 15 merupakan halaman client yang digunakan client untuk mengelola seminar yang diadakan client itu sendiri, menu-menu yang terdapat pada halaman clinet seperti pengelolaan data seminar, data user, data pembayaran user, data Qr Code user, data kehadiran user dan menu scanner untuk membaca Qr Code user.

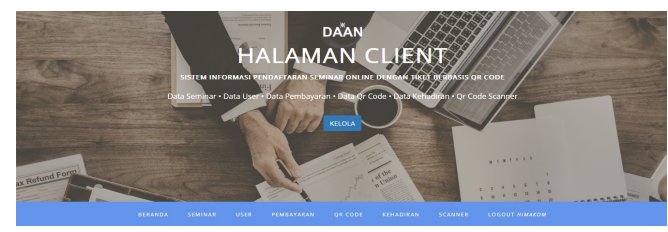

Gambar 15. Halaman client

Pada halaman user pada seminar berbayar berisi menumenu seperti prosedur seminar, pembayaran, unduh tiket dan informasi seminar. Halaman user pada seminar berbayar dapat dilihat pada Gambar 16. Sedangkan pada Gamabr 17 merupakan halaman user pada seminar gratis yang berisi menu-menu seperti prosedur seminar, generate tiket, unduh tiket dan informasi seminar.

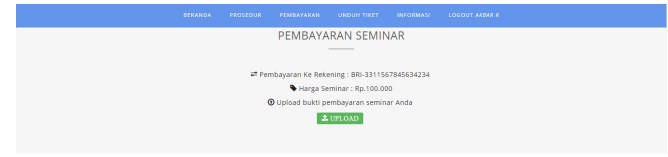

Gambar 16. Halaman user berbayar

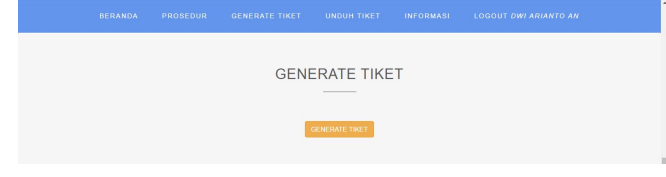

Gambar 17. Halaman user gratis

Gambar 18 merupakan tiket seminar. Tikat seminar ini didapatkan ketika user sudah melakukan pembayaran seminar. Hasil tiket seminar tersebut berbentuk file PDF dimana file ini berisi data seminar yang diikuti user, data user itu sendiri dan Qr Code. Data Qr Code tersebut digunakan user untuk memasuki seminar yang diikutinya.

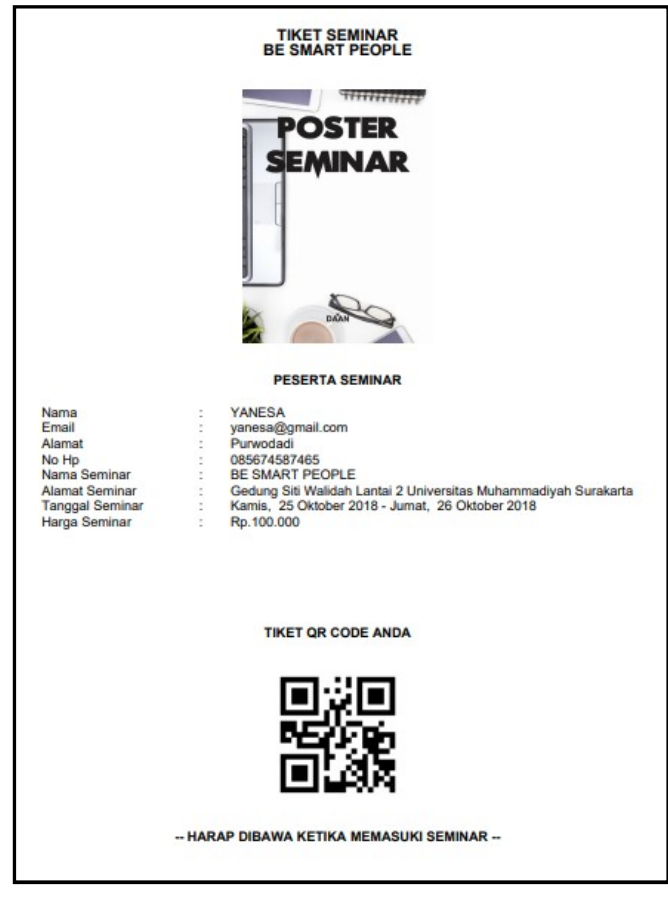

Gambar 18. Tiket Seminar

Untuk membaca Qr Code yang telah diunduh user, menu untuk membaca Qr Code tersebut terdapat pada menu scanner yang dapat diakses oleh client. Setelah webcam membaca Qr Code yang sudah di unduh user, data kehadiran akan terisi secara otomatis. Halaman impelementasi sistem dapat dilihat pada Gambar 19. 
Gambar 19. Hasil implementasi sistem

\section{B. Pengujian dan Pembahasan}

Proses pengujian sistem ini dilakukan untuk memastikan apakah sistem berjalan sesuai rencana awal yang telah dibuat atau tidak dan untuk mengetahui letak kesalahan yang ada pada sistem. Pengujian sistem ini dilakukan pada beberapa hal, yaitu :

\section{1) Pengujian Perangkat Qr Code}

Tujuan dari perangkat ini adalah untuk mengetahui bagaimana kemampuan jangkauan dan batasan yang ada pada Qr Code. Perangkat yang digunakan untuk membaca Qr Code adalah webcam. Tabel 1 merupakan hasil pengujian pada webcam.

TABEL 1. Pengujian PerangKat QR CODE

\begin{tabular}{|c|c|c|}
\hline No & Nama Pengujian & Hasil \\
\hline 1 & $\begin{array}{c}\text { Jarak terjauh membaca data } \\
\text { Qr Code pada tiket tanpa ada } \\
\text { penghalang }\end{array}$ & $25-30 \mathrm{~cm}$ \\
\hline 2 & $\begin{array}{c}\text { Jarak terdekat membaca Qr } \\
\text { Code pada tiket tanpa ada } \\
\text { penghalang }\end{array}$ & $10-15 \mathrm{~cm}$ \\
\hline 3 & $\begin{array}{c}\text { Pencahayaan pada saat } \\
\text { membaca Qr Code pada tiket }\end{array}$ & $\begin{array}{c}\text { Proses membaca data Qr Code } \\
\text { harus ada pencahayaan, jika } \\
\text { tidak data tidak bisa dibaca }\end{array}$ \\
\hline
\end{tabular}

\section{2) Pengujian Sistem}

Pengujian sistem ini diterapkan pada organisasi Kine Club UMS yang dilakukan oleh seluruh panitia penyelengara Roadshow Proyek Filem Hitam Putih Milisifilem. Tabel 2 dan 3 merupakan hasil pengujian sistem.

TABEL 2. PENGUJIAN SISTEM

\begin{tabular}{|c|c|c|c|c|}
\hline No & Input & Fungsi & Output & Hasil \\
\hline 1 & $\begin{array}{c}\text { Panitia } \\
\text { mendaftarkan } \\
\text { acara }\end{array}$ & $\begin{array}{l}\text { Membuat } \\
\text { data acara } \\
\text { yang akan } \\
\text { diselenggara } \\
\text { kan dan } \\
\text { dikelola }\end{array}$ & $\begin{array}{c}\text { Acara bisa } \\
\text { dipilih } \text { user } \\
\text { pada halaman } \\
\text { utama dan } \\
\text { panitia bisa } \\
\text { mengelola } \\
\text { acara tersebut }\end{array}$ & Sesuai \\
\hline
\end{tabular}

TABEL 3. PENGUJiAn Sistem (LANJUTAN)

\begin{tabular}{|c|c|c|c|c|}
\hline No & Input & Fungsi & Output & Hasil \\
\hline 2 & $\begin{array}{c}\text { Panitia melakukan } \\
\text { login dengan } \\
\text { memasukan } \text { email } \\
\text { dan password } \\
\text { yang telah } \\
\text { diberikan oleh } \\
\text { admin }\end{array}$ & $\begin{array}{c}\text { Mengelola } \\
\text { acara yang } \\
\text { diselenggara } \\
\text { panitia }\end{array}$ & $\begin{array}{c}\text { Menampilkan } \\
\text { halaman } \text { client }\end{array}$ & Sesuai \\
\hline 3 & $\begin{array}{c}\text { Panitia menekan } \\
\text { tombol detail }\end{array}$ & $\begin{array}{c}\text { Menampilka } \\
\text { n deskripsi }\end{array}$ & $\begin{array}{c}\text { Menampilkan } \\
\text { halaman }\end{array}$ & Sesuai \\
\hline
\end{tabular}

\begin{tabular}{|c|c|c|c|c|}
\hline No & Input & Fungsi & Output & Hasil \\
\hline & deskripsi acara & acara & $\begin{array}{c}\text { deskripsi } \\
\text { acara }\end{array}$ & \\
\hline 4 & $\begin{array}{c}\text { Panitia menekan } \\
\text { tombol edit data } \\
\text { acara }\end{array}$ & $\begin{array}{c}\text { Mengubah } \\
\text { data acara } \\
\text { jika ada } \\
\text { perubahan } \\
\text { data }\end{array}$ & $\begin{array}{c}\text { Menampilkan } \\
\text { halaman untuk } \\
\text { mengubah } \\
\text { data acara }\end{array}$ & Sesuai \\
\hline 5 & $\begin{array}{c}\text { Panitia menekan } \\
\text { tombol edit data } \\
\text { user }\end{array}$ & $\begin{array}{l}\text { Mengubah } \\
\text { data dari } \\
\text { user }\end{array}$ & $\begin{array}{l}\text { Menampilkan } \\
\text { halaman untuk } \\
\text { mengubah } \\
\text { data } \text { user }\end{array}$ & Sesuai \\
\hline 6 & $\begin{array}{l}\text { Panitia menekan } \\
\text { tombol delete data } \\
\text { user }\end{array}$ & $\begin{array}{l}\text { Menghapus } \\
\text { data } u \text { ser }\end{array}$ & $\begin{array}{l}\text { Data user } \\
\text { terhapus }\end{array}$ & Sesuai \\
\hline 7 & $\begin{array}{l}\text { Panitia menekan } \\
\text { tombol export data } \\
\text { user ke dokumen } \\
\text { Excel. }\end{array}$ & $\begin{array}{c}\text { Membuat } \\
\text { data } u s e r \\
\text { menjadi } \\
\text { dokumen } \\
\text { Excel }\end{array}$ & $\begin{array}{l}\text { Data_user.xls } \\
\text { diunduh }\end{array}$ & Sesuai \\
\hline 8 & $\begin{array}{l}\text { Panitia menekan } \\
\text { tombol detail data } \\
\text { pembayaran } u \text { ser } \\
\text { (Berbayar) }\end{array}$ & $\begin{array}{c}\text { Melihat } \\
\text { bukti } \\
\text { pembayaran } \\
\text { user }\end{array}$ & $\begin{array}{c}\text { Menampilkan } \\
\text { halaman bukti } \\
\text { pembayaran } \\
\text { user }\end{array}$ & Sesuai \\
\hline 9 & $\begin{array}{c}\text { Panitia menekan } \\
\text { tombol update } \\
\text { data pembayaran } \\
\text { user }\end{array}$ & $\begin{array}{l}\text { Mengubah } \\
\text { data } \\
\text { pembayaran } \\
\text { user dari } \\
\text { belum } \\
\text { membayar } \\
\text { ke sudah } \\
\text { membayar }\end{array}$ & $\begin{array}{c}\text { Menampilkan } \\
\text { halaman } \\
\text { update } \\
\text { pembayaran } \\
\text { user }\end{array}$ & Sesuai \\
\hline 10 & $\begin{array}{l}\text { Panitia menekan } \\
\text { tombol detail data } \\
\text { Qr Code user }\end{array}$ & $\begin{array}{l}\text { Melihat data } \\
\text { Qr Code user }\end{array}$ & $\begin{array}{c}\text { Menampilkan } \\
\text { halaman detail } \\
\text { Qr Code user }\end{array}$ & Sesuai \\
\hline 11 & $\begin{array}{c}\text { Panitia menekan } \\
\text { tombol delete data } \\
\text { Qr Code }\end{array}$ & $\begin{array}{c}\text { Menghapus } \\
\text { data Qr Code } \\
\text { user }\end{array}$ & $\begin{array}{l}\text { Data Qr Code } \\
\text { user terhapus }\end{array}$ & Sesuai \\
\hline 12 & $\begin{array}{l}\text { Panitia menekan } \\
\text { tombol export } \\
\text { data kehadiran ke } \\
\text { dokumen Excel }\end{array}$ & $\begin{array}{c}\text { Membuat } \\
\text { data } \\
\text { kehadiran } \\
\text { menjadi } \\
\text { dokumen } \\
\text { Excel }\end{array}$ & $\begin{array}{c}\text { Data_kehadira } \\
\text { n.xls diunduh }\end{array}$ & Sesuai \\
\hline 13 & $\begin{array}{l}\text { Pantia memilih } \\
\text { menu scanner } \\
\text { pada sesi } 1 \text { sampai } \\
3 \text { dan menekan } \\
\text { tombol start } \\
\text { scanning }\end{array}$ & $\begin{array}{l}\text { Membaca Qr } \\
\text { Code user } \\
\text { yang } \\
\text { mengikuti } \\
\text { acara } \\
\text { tersebut }\end{array}$ & $\begin{array}{l}\text { Menampilkan } \\
\text { halaman } \\
\text { scanner dan } \\
\text { membaca data } \\
\text { Qr Code user } \\
\text { berdasarkan } \\
\text { sesi yang } \\
\text { dipilih }\end{array}$ & Sesuai \\
\hline 14 & $\begin{array}{l}\text { Panitia memilih } \\
\text { menu logout }\end{array}$ & $\begin{array}{c}\text { Keluar dari } \\
\text { halaman } \\
\text { client }\end{array}$ & $\begin{array}{l}\text { Menampilkan } \\
\text { halaman login }\end{array}$ & Sesuai \\
\hline
\end{tabular}

Setelah melakukan pengujian, berdasarkan hasil pada tabel 2 dan 3 dapat disimpulkan bahwa sistem berjalan sesuai rencana awal. Fitur-fitur yang ada pada sistem berjalan dengan baik dan efisien serta membantu panitia dalam mengelola acara tersebut.

\section{3) Pengujian Sistem oleh Pengguna}

Pengujian ini dilakukan oleh pengguna atau peserta yang mengikuti acara tesebut. Peserta harus mendaftarkan dirinya terlebih dahulu pada sistem yang sudah disediakan, lalu 
peserta nantinya akan mendapatkan tiket berupa Qr Code yang nantinya digunakan sebagai akses masuk. Setiap pengguna diberikan lembar kuesioner untuk memberikan tanggapan mengenai sistem. Untuk pernyataan yang akan diajukan kepada para responden dalam indikator usability, diberikan pernyataan :

\section{"Tampilan mudah dipahami."}

"Sistem (cara penggunaan) mudah dipahami."

"Sistem perlu dikembangkan."

Dalam indikator efisiensi, responden diberikan pertanyaan :

"Sistem tersebut membantu proses pendaftaran dan akses masuk di sebuah acara seminar workshop."

"Sistem tersebut efisien."

Pada tabel 4 merupakan nilai (score) untuk setiap pilihan jawabannya.

TABEL 4. KETERANGAN Nilai (SCORE)

\begin{tabular}{|c|c|}
\hline Input & Nilai \\
\hline Sangat Setuju (SS) & 4 \\
\hline Setuju (S) & 3 \\
\hline Tidak Setuju (TS) & 2 \\
\hline Sangat Tidak Setuju (STS) & 1 \\
\hline
\end{tabular}

Perhitungan hasil kuesioner dihitung dengan rumus 1 :

Persentase $=\frac{\sum \text { Skor } x 100 \%}{S \operatorname{Max}}$

Pada pengujian ini memiliki total 51 responden sehingga contoh perhitungannya dapat dilihat dibawah ini :

Skor tertinggi $(\mathbf{S M a x})=4 \times \mathrm{n}=4 \mathrm{n}(\mathrm{SS})$

Skor terendah $($ SMin) $=1 \times \mathrm{n}=1 \mathrm{n}(\mathrm{STS})$

n merupakan total responden sehingga :

$\sum$ Skor $=\sum(\mathrm{SS}+\mathrm{S}+\mathrm{TS}+\mathrm{STS})$

$=(41 \times 4)+(10 \times 3)+(0 \times 2)+(0 \times 1)$

$=164+30+0+0=198$

Persentase $=\frac{\sum \text { Skor } x 100 \%}{\text { SMax }}$

Persentase $=\frac{\sum 198 \times 100 \%}{204}=97.05 \%$

TABEL 5. TABEL HASIL KUESIONER

\begin{tabular}{|c|c|c|c|c|c|c|c|}
\hline \multirow{2}{*}{ No } & Pernyataan & \multicolumn{4}{|c|}{ Jawaban } & \multirow{2}{\text{Juml}}{$\begin{array}{c}\text { Present } \\
\text { ah } \\
\text { Skor }\end{array}$} & $\begin{array}{c}\text { SS } \\
\text { ase }\end{array}$ \\
\hline 1 & $\begin{array}{c}\text { Tampilan } \\
\text { mudah di } \\
\text { pahami. }\end{array}$ & 41 & 10 & 0 & 0 & 198 & $97.05 \%$ \\
\hline
\end{tabular}

\begin{tabular}{|c|c|c|c|c|c|c|c|}
\hline & $\begin{array}{c}\text { Sistem } \\
\text { tersebut } \\
\text { membantu } \\
\text { proses } \\
\text { pendaftaran } \\
\text { dan akses } \\
\text { masuk di } \\
\text { sebuah acara } \\
\text { seminar/wor } \\
\text { kshop. }\end{array}$ \\
\hline 3 & 29 & 22 & 0 & 0 & 182 & $89.21 \%$ \\
\hline $\begin{array}{c}\text { Tampilan } \\
\text { mudah di } \\
\text { pahami. }\end{array}$ & 34 & 15 & 1 & 1 & 184 & $90.19 \%$ \\
\hline 5 & $\begin{array}{c}\text { Sistem } \\
\text { tersebut } \\
\text { efisien. }\end{array}$ & 33 & 16 & 2 & 0 & 184 & $90.19 \%$ \\
\hline $\begin{array}{c}\text { Sistem perlu } \\
\text { dikembangka } \\
\text { n. }\end{array}$ & 36 & 13 & 1 & 0 & 185 & $90.68 \%$ \\
\hline \multicolumn{7}{|c|}{ Total } \\
\hline
\end{tabular}

Tabel 5 diatas menunjukan hasil kuesioner yang di isi oleh peserta acara pengguna sistem yang mencapai nilai $91.47 \%$ yang membuktikan bahwa sistem ini efisien dan layak diterapkan.

\section{Penutup}

Berdasarkan perancangan dan pembuatan sistem pendaftaran seminar dengan tiket berbasis Qr Code dapat disimpulkan sebaigai berikut :

1) Sistem bekerja dengan baik sesuai dengan rancangan awal dan fitur-fitur yang ada pada sistem berjalan dengan baik, efisien serta membantu panitia dalam mengelola acara tersebut.

2) Perangkat webcam yang digunakan untuk membaca data QR Code juga berjalan dengan baik di pencahayaan yang cukup terang dalam jarak $20-30 \mathrm{~cm}$.

3) Hasil pengujian sistem ini menggunakan blackbox juga berjalan dengan baik.

4) Pengujian yang melibatkan peserta acara yang menggunakan sistem ini memberikan tanggapan melalui kuesioner mencapai $91.47 \%$ yang membuktikan bahwa sistem ini efisien dan layak diterapkan.

\section{DAFTAR PUSTAKa}

[1] Tiwari, S. (2016). An Introduction To QR Code Technology, International Conference on Information Technology, 4(3), 39-44.

[2] Talip, B. A. (2018). Mobile Attendance System Using Qr Codes Technology, Journal of Computing Technologies and Creative Content, $3(1), 1-3$.

[3] Hendry, R., Rahman, M. N. A., \& Seyal, A. H. (2017). Smart Attendance System Applying QR Code, 12th International Conference on Latest Trends in Engineering and Technology May 22-24, 2017 Kuala Lumpur (Malaysia), 1-5.

[4] Kaur, S. (2017). QR Code Security and Solution, International Journal of Engineering Science and Computing, 7(4), 10323-10325.

[5] Barjtya, S., Sharma, A., \& Rani, U. (2017). A detailed study of Software Development Life Cycle ( SDLC ) Models, International Journal Of Engineering And Computer Science, 6(7), 22097-22100). 